\title{
Peran Komunikasi dalam Proses Modernisasi Masyarakat Desa Pertanian
}

\author{
Dinna Eka Graha Lestari a, $1^{*}$, \\ a IKIP Budi Utomo Malang, Jalan Cintadui No. 46 Malang, 65122, Indonesia \\ 1 dynna_lestari@yahoo.com \\ * Corresponding Author
}

\begin{tabular}{ll}
\hline INFO ARTIKEL & ABSTRAK \\
\hline Sejarah Artikel: & Pembangunan pertanian modern sangat ditentukan oleh percepatan \\
Diterima: 14 Oktober & peningkatan produktivitas, kualitas, dan nilai tambah produksi dengan \\
2020 & pendekatan agribisnis dan agroindustri. Sejak perkembangan revolusi \\
Direvisi: 1 November & hijau, teknologi pertanian dan manajemen bisnis pertanian di dalam negeri \\
2020 & berkembang pesat, terutama dalam meningkatkan produksi berbagai \\
Disetujui: 9 November & komoditas pangan melalui program pembangunan yang direncanakan oleh \\
2020 & pemerintah. Untuk mendorong peningkatan kapasitas petani menuju \\
Tersedia Daring: 16 & terwujudnya pertanian yang lebih modern pemerintah memberikan \\
November 2020 & pembinaan pendekatan top down melalui program penyuluhan dan \\
\hline Kata Kunci: & penyebaran tenaga penyuluh lapangan (PPL). Memasuki era globalisasi \\
Desa Pertanian & dengan perkembangan teknologi komunikasi yang sangat dinamis \\
Komunikasi & membutuhkan model pembangunan pertanian modern yang berkelanjutan \\
Masyarakat & dengan pendekatan agribisnis dan agroindustri untuk daya saing petani \\
Modernisasi & berdasarkan penguatan koperasi pertanian petani. Tujuan tulisan ini adalah \\
& mendeskripsikan peran komunikasi dalam menumbuhkan proses \\
& modernisasi pada masyarakat desa pertanian. Peran komunikasi \\
& pembangunan dalam modernisasi semakin penting seiring dengan \\
& kemajuan iptek dan perkembangan globalisasi yang menuntut kemandirian \\
dan daya saing petani. Komunikasi budaya yang dibangun melibatkan
\end{tabular}

\begin{tabular}{|c|c|}
\hline & ABSTRACT \\
\hline $\begin{array}{l}\text { Keywords: } \\
\text { Agricultural Village } \\
\text { Communication } \\
\text { Society } \\
\text { Modernization }\end{array}$ & $\begin{array}{l}\text { Modern agricultural development is largely determined by the acceleration } \\
\text { of productivity improvement, quality and value-added production to } \\
\text { agribusiness and agro-industry approach. Since the development of the } \\
\text { green revolution, agricultural technology and agricultural business } \\
\text { management in the country has developed rapidly, especially in increasing } \\
\text { the production of various food commodities through the development } \\
\text { program planned by the government. To encourage increased capacity of } \\
\text { farmers towards the realization of a more modern agriculture the } \\
\text { government to provide top down approach guidance through the extension } \\
\text { program and the spread of agricultural extension field workers (PPL). } \\
\text { Entering the era of globalization with a very dynamic communication } \\
\text { technologies development require a sustainable modern agriculture } \\
\text { development model with agribusiness and agro-industry approach to } \\
\text { farmer competitiveness based on strengthening farmer agricultural } \\
\text { cooperative. The purpose of this paper is to describe the role of cultural } \\
\text { communication in fostering the modernization process in agricultural } \\
\text { village communities. The role of development communication in } \\
\text { modernization is increasingly important in line with advances in science } \\
\text { and technology and the development of globalization which demands the } \\
\text { independence and competitiveness of farmers. Cultural communication that } \\
\text { is built involves all parties involved, both from the government and the }\end{array}$ \\
\hline
\end{tabular}


community. This agricultural development is based on sustainable development.

How to Cite: Lestari, D. E. G. (2020). Peran Komunikasi dalam Proses Modernisasi Masyarakat Desa Pertanian. JURNAL SATWIKA, 4 (2), 150-156. doi: https://doi.org/10.22219/SATWIKA.Vol4.No2.150-156.

\section{Pendahuluan}

Pembangunan pertanian modern merupakan langkah strategis mewujudkan pembangunan pertanian berkelanjutan sebagai paradigma baru, sehingga dapat meningkatkan daya beli masyarakat perdesaan yang akan menjadi pendorong pertumbuhan sektor non-pertanian. Pembangunan pertanian modern adalah suatu rangkaian panjang dari perubahan atau peningkatan kapasitas, kualitas, profesionalitas, dan produktivitas tenaga kerja pertanian. Selain itu juga diiringi dengan penataan dan pengembangan lingkungan fisik dan sosialnya sebagai manifestasi dari akumulasi dan aplikasi kemajuan teknologi dan kekayaan material serta organisasi dan manajemen.

Sejak dikembangkannya gerakan revolusi hijau, pemanfaatan berbagai teknologi, seperti teknologi kimia dan teknologi alat dan mesin pertanian (Alsintan) telah terjadi peningkatan produktivitas pertanian yang sangat pesat. Namun, di sisi lain terjadi kerusakan lingkungan hidup dan tatanan kehidupan sosial di perdesaan. Proses adopsi inovasi teknologi baru di lingkungan petani telah terjadi berkat dukungan sistem komunikasi pembangunan yang dikembangkan oleh pemerintah.

Oleh karena pendekatan pembangunan pertanian pada waktu itu sangat memperhatikan persuasi dan propaganda, maka pemerintah mengacu kepada model komunikasi linier (satu arah) dan berbentuk vertikal dari atas ke bawah (top-down). Sejak pasca swasembada pangan tahun 1984 terjadi kecenderungan melambatnya adopsi inovasi teknologi pertanian dalam peningkatan produksi, seperti terlihat dari gejala stagnasi atau pelandaian produktivitas berbagai produksi komoditas pertanian dan pendapatan, serta kesejahteraan petani di perdesaan. Setelah model komunikasi linier satu arah dianggap kurang sempurna, kini pandangan orang mulai mengarah pada komunikasi interaktif dua arah di antara partisipan.

Modernisasi pertanian di masa depan sangat tergantung kepada manfaat optimal dari teknologi yang diperoleh oleh petani dan tidak merusak lingkungan. Teknologi pertanian harus mampu menyesuaikan diri dengan perkembangan global, yakni berdaya saing dan ramah lingkungan. Akses petani dalam memperoleh informasi dari berbagai sumber telah terbuka luas sehingga dalam waktu singkat akan menjadi bagian dari masyarakat informasi untuk memanfaatkannya bagi percepatan moderniasi pertanian. Paradigma pembangunan saat ini mengalami pergeseran, di mana pembangunan menekankan pada pemberdayaan (empowerment) yang dikenal dengan pembangunan manusia (people centered development), pembangunan berbasis sumber daya lokal (resource based development), dan pembangunan kelembagaan (institutional development).

Dalam hal ini, peran komunikasi pembangunan dua arah (convergent) di perdesaan menjadi penting agar petani dapat memperoleh informasi dan menentukan teknologi pertanian yang tepat untuk digunakandan manajemen usaha tani yang semakin maju. Sistem agribisnis dan agroindustri merupakan pendekatan pengembangan usaha tani modern dengan memperhatikan aspek lingkungan hidup, nilai tambah, dan daya saing petani. Berkaitan dengan program otonomi daerah 
yang sedang dikembangkan oleh pemerintah Indonesia, komunikasi pembangunan pertanian untuk percepatan kemandirian petani dan peningkatan daya saing menuju pertanian berkelanjutan yang modern, merupakan alternatif kebijakan yang perlu dipertimbangkan oleh pemerintah daerah. Pemahaman keberagaman sumber daya alam dan sumber daya manusia dengan karakteristiknya yang khas pada setiap daerah menjadi landasan pokok untuk membangun pertanian modern di masa depan. Proses adopsi inovasi teknologi dan jaringan komunikasi petani yang ditemukan di daerah melalui penguatan koperasi pertanian akan sangat mempengaruhi efektivitas komunikasi pembangunan. Permasalahan yang dihadapi di lapangan adalah bagaimana pola komunikasi yang efektif agar proses komunikasi dalam pemanfaatan informasi yang tersedia dapat secara optimal mendorong percepatan modernisasi pertanian berbasis koperasi. Kerjasama antarpelaku ekonomi di pedesaan juga dapat berlangsung efektif.

Tulisan ini bertujuan memaparkan peran komunikasi dalam proses modernisasi masyarakat pertanian. Persoalan ini penting karena Nasrulloh (2015) dalam studinya memperlihatkan bahwa komunikasi budaya yang berbeda sangat berpengaruh terhadap perkembangan sosioteknologi di internet. Selain itu Hasan, Asmawi, \& Rasul (2018) memperlihatkan bahwa pendekatan kultural sangat efektif untuk berkomunikasi dengan masyarakat. Selain itu, Arroisi \& Quraisyin (2015), juga memperlihatkan bahwa hubungan kekerabatan di antara masyarakat sangat berkaitan erat dengan komunikasi di antara sesamanya. Hal tersebut memperlihatkan bahwa pentingnya komunikasi dalam segala aspek kehidupan. Hal ini utamanya berkaitan dengan pembangunan manusia melalui implementasi kebijakan-kebijkan yang berasal dari pemerintah.

\section{Pembahasan}

\subsection{Paradigma Pembangunan Pertanian}

Pembangunan Nasional merupakan rangkaian upaya pembangunan yang berkesinambungan, meliputi seluruh aspek kehidupan masyarakat, bangsa dan negara untuk melaksanakan tugas mewujudkan tujuan nasional. Steers (1985) mengemukakan bahwa pembangunan sebagai upaya membangkitkan masyarakat di negara-negara sedang berkembang bertujuan mengatasi masalah kemiskinan, tingkat melek huruf yang rendah, pengangguran dan ketidakadilan. Berdasarkan Undang-Undang (UU) No. 17 tahun 2007 tentang RPJPN tahun 2005-2025, visi pembangunan Nasional tahun 2005-2025 bertujuan mencapai Indonesia yang mandiri, maju, adil dan makmur. Visi pembangunan Nasional tersebut ditempuh melalui delapan misi yang mencakup 1) mewujudkan masyarakat berakhlak mulia, bermoral, beretika, berbudaya dan beradab berdasarkan falsafah Pancasila, 2) mewujudkan bangsa yang berdaya saing, 3) mewujudkan masyarakat demokratis berlandaskan hukum, 4) mewujudkan Indonesia aman, damai, dan bersatu, 5) mewujudkan pemerataan pembangunan dan berkeadilan, 6) mewujudkan Indonesia asri dan lestari, 7) mewujudkan Indonesia menjadi negara kepulauan yang mandiri, maju, kuat dan berbasiskan kepentingan nasional, dan 8) mewujudkan Indonesia berperan penting dalam pergaulan dunia Internasional (Umar 2017).

Untuk mempercepat modernisasi pertanian, peningkatan produktivitas dan nilai tambah ekonomi diperlukan paradigma baru yang dikaitkan dengan pemanfaatan informasi melalui komunikasi pembangunan pertanian berbasis koperasi yang profesional berdasarkan prinsip-prinsip perkoperasian. Modernisasi pertanian harus mampu menghindari kerusakan-kerusakan struktur tanah, polusi air, pencemaran lingkungan akibat penggunaan pupuk dan pestisida, serta penggunaan alsintan yang tidak ramah lingkungan. Pertanian lestari menjadi pilihan utama yang telah muncul sebagai gerakan 
pertanian berkelanjutan (sustainable agriculture) sejak awal 1990-an. Munculnya gerakan ini semula dipelopori oleh para pecinta lingkungan yang khawatir terjadi kerusakan alam secara terus-menerus akibat penggunaan bahan-bahan kimia serta punahnya berbagai keanekaragaman hayati di muka Bumi. Gerakan ini mendorong perubahan dalam praktik-praktik usaha tani. Penggunaan bahan-bahan kimia (pupuk dan pestisida) dikurangi, kembali ke cara-cara tradisional yang menghargai potensi lokal, menempatkan petani sebagai subjek pertanian, mengelola usaha tani sesuai dengan budaya dan lingkungan setempat, serta mengupayakan perdagangan yang adil (fair trade).

Pendekatan dan strategi yang dikembangkan dalam model pertanian berkelanjutan ini dilakukan dengan cara mendorong tumbuhnya sumber-sumber pendapatan keluarga petani di pedesaan dengan pendekatan agribisnis dan agroindustri. Strategi agribisnis yang telah dikembangkan mencakup dua aspek, yakni kegiatan pada on farm (di lahan pertanian) dan kegiatan pada off farm (di luar lahan pertanian). Model on farm yang dikembangkan tidak harus kembali pada model tradisional yang sudah ada, tetapi perlu disesuaikan dengan situasi lingkungan yang sudah berubah. Selain itu juga kebutuhan pangan dan ekonomi yang semakin besar. Prinsip pengelolaan pertanian berkelanjutan adalah multikultur, menghargai keanekaragaman hayati, menghargai kearifan lokal, memanfaatkan bahan-bahan lokal, tidak bergantung bahan luar, tidak mengekploitasi alam serta sesuai budaya dan pilihan serta kemampuan petani. Prinsip-prinsip tersebut menumbuhkan beragam model pertanian berkelanjutan di berbagai belahan dunia.

Petani kecil yang seringkali mempunyai keterbatasan dalam mengakses sarana dan prasarana produksi pertanian, melalui pertanian lestari mempunyai peluang yang luas dalam membangun usaha pertaniannya. Kepercayaan petani kembali tumbuh karena bisa membuat keputusan sendiri terhadap usaha taninya serta mampu membuat benih pupuk dan pestisida sendiri, mempunyai organisasi serta jaringan antarpetani. Gerakan pertanian berkelanjutan yang terjadi di hampir setiap negara, terutama negaranegara Amerika, Eropa dan Asia selama 10 tahun terakhir ini menunjukkan perubahanperubahan yang menarik. Perubahan yang muncul antara lain 1) gerakan konsumen hijau, yakni perubahan kesadaran dan pola konsumen terhadap produk pangan yang ramah lingkungan (organik) meningkat dan 2) gerakan konsumen ini sangat mendukung upaya penyelamatan lingkungan dan menekan perusahaan pertanian dalam memproduksi barang dan jasa agar menggunakan etika kemanusiaan dan lingkungan. IFOAM adalah salah satu lembaga independen yang diakui bisa memberikan sertifikasi organik.

Dengan kondisi petani saat ini yang masih serba lemah, baik penguasaan lahan, modal, maupun teknologi diperlukan multiapproach, yakni pendekatan modernisasi, kemandirian dan partisipatif. Untuk maksud tersebut peran koperasi pertanian yang semakin profesional merupakan kebutuhan petani sehingga mempunyai daya saing dan kemampuan meningkatkan nilai tambah bagi petani. Untuk percepatan pembangunan koperasi pertanian perlu dilakukan penataan KUD yang sudah ada agar semakin profesional dengan kinerja dan kapasitas yang semakin meningkat dengan pemanfaatan informasi yang tersedia secara optimal. Dengan demikian peran komunikasi pembangunan pertanian dan komunikasi organisasi koperasi dengan pola dua arah dengan pendekatan sistem agribisnis dan agroind ustri, pertanian berkelanjutan, komoditas unggulan, teknologi tepat guna, daya saing serta kesejahteraan anggota semakin penting.

\subsection{Komunikasi Pembangunan}

Konsep pembangunan pertanian semakin berkembang menuju pertanian modern seiring dengan perkembangan ilmu pengetahuan dan teknologi (iptek) dalam bidang teknologi dan manajemen pertanian 
yang didukung oleh perkembangan teknologi komunikasi yang sangat cepat. Sejarah perekonomian dunia telah menunjukkan bahwa peran pertanian semakin penting untuk meningkatkan kesejahteraan dan ketahanan Nasionalnya. Upaya pemberdayaan petani dimaksudkan untuk meningkatkan kemampuannya agar mempunyai kemandirian dan dan daya saing dengan posisi tawar yang seimbang melalui sistem kemitraan usaha. Perkembangan globalisasi perdagangan yang cepat memberi dampak terhadap peran komunikasi dalam pembangunan pertanian untuk meningkatkan produktivitas dan kualitas produksi yang berdaya saing dan mampu meningkatkan kesejahteraan petani.

Komunikasi merupakan suatu proses penyampaian pesan oleh komunikator kepada komunikan dan terjadi saling pengertian, pemahaman yang sama terhadap pesan yang disampaikan. Efek komunikasi adalah perubahan pada perilaku individu dan dapat berdampak pada lingkungan individu. Efek komunikasi adalah adanya perubahan yang terjadi pada diri khalayak, yakni perubahan kognitif, afektif, dan behavioral. Bila komunikasi terus menerus berlangsung akan terjadi interaksi yaitu saling mempengaruhi antara individu yang satu dengan yang lain. Secara umum komunikasi mempunyai fungsi untuk menyampaikan suatu informasi dalam sistem sosial terkait dengan pendidikan, hiburan dan mempengaruhi perilaku. Selanjutnya Middleton (dalam Jahi, 1988), mengungkapkan bahwa terdapat empat pendekatan komunikasi yang dapat menimbulkan perubahan perilaku khalayak sasaran, yakni menyampaikan informasi, instruksi, persuasi, dan dialog.

Pada proses penyampaian satu arah, yakni dari komunikator kepada komunikan dan pada umumnya dilakukan oleh pemerintah kepada masyarakat secara hierarkis ke bawah. Model komunikasi satu arah dikembangkan oleh negara-negara dunia ketiga yang menggunakan teori modernisasi dalam melaksanakan pembangunannya. Komunikasi telah berperan dalam membantu mempercepat proses peralihan masyarakat tradisional menjadi masyarakat modern, khususnya peralihan dari kebiasaankebiasaan yang menghambat pembangunan ke arah sikap baru yang tanggap terhadap pembaharuan. Arus komunikasi satu arah dari badan-badan pembangunan pemerintah kepada masyarakat sangat mencolok. Media massa dapat secara cepat menjangkau khalayak luas dengan pesan-pesan yang informatif mengenai berbagai hal tentang pembangunan (Muhammad, 2004).

Dalam komunikasi akan terjadi suatu proses yang memungkinkan komponenkomponen suatu sistem sosial memperoleh dan bertukar informasi yang dibutuhkan dengan pihak lain. Sistem sosial tersebut memerlukan informasi untuk menyesuaikan diri dan menjaga keseimbangan dengan lingkungannya untuk berubah setiap saat. Penyesuaian diri sistem sosial dengan lingkungannya tersebut akan mengalami perubahan dan perubahan-perubahan tersebut dapat diartikan sebagai pembangunan. Menurut Rogers (1976) dalam perkembangannya istilah pembangunan banyak digunakan terkait dengan upaya melakukan perubahan sosial ekonomi. Kepincangan sosial ekonomi yang terjadi di negara-negara dunia ketiga, mengalihkan pemikiran para pakar untuk melahirkan konsep pembangunan yang lebih memperhatikan kemajuan sosial, persamaan, dan kebebasan. Adanya pergeseran ini menimbulkan pengertian pembangunan sebagai suatu proses perubahan sosial dalam suatu masyarakat yang diselenggarakan dengan jalan memberi kesempatan yang seluas-luasnya pada warga masyarakat berpartisipasi untuk memdapatkan kemajuan, baik secara sosial maupun material.

Dalam hal ini termasuk pemerataan, kebebasan dan berbagai kualitas lain yang diinginkan agar menjadi lebih baik bagi mayoritas warga masyarakat dalam suatu lingkungan hidup yang lebih baik. Berarti konsep pembangunan telah bertambah luas dan menjadikannya jauh lebih fleksibel dan sekaligus memiliki implikasi yang lebih 
manusiawi. Seiring dengan hal tersebut, konsep paradigma pembangunan mengisyaratkan bahwa peranan komunikasi dalam pembangunan semakin penting.

Teori pembangunan sebagai pola pikir yang berfungsi mengupas dan memecahkan persoalan-persoalan pembangunan, muncul bersamaan pada saat para pakar mencoba membahas pembangunan sekitar tahun 40an hingga tahun 60an, di mana saat itu banyak negara-negara yang baru merdeka. Berbagai tantangan dihadapi oleh negara-negara baru tersebut, terutama keterbelakangan di bidang ekonomi. Usaha untuk mengejar ketertinggalan tersebut ditempuh melalui pembangunan. Sejak itu teori pembangunan mulai digunakan sebagai resep bagi negara dunia ketiga yang padat penduduk untuk menciptakan perubahan yang lebih baik bagi kesejahteraan masyarakatnya. Konsep pembangunan memiliki banyak teori yang melatarbelakanginya, seperti teori modernisasi, teori ketergantungan dan keterbelakangan, serta teori penyadaran. Teori modernisasi melahirkan model pembangunan yang berorientasi pada pertumbuhan. Sedangkan teori ketergantungan dan keterbelakangan berkembang akibat proses eksploitasi dan ekspansi ekonomi dari perusahaan multinasional dari negara-negara maju ke negara-negara dunia ketiga atau negaranegara berkembang. Teori penyadaran timbul dari hasil belajar memahami kontradiksi sosial, politik, serta pengambilan tindakan untuk menghindari unsur-unsur yang menimbulkan kerugian pada masyarakat.

Menurut Freire (1984) teori penyadaran merupakan solusi terhadap keterbelakangan yang banyak dialami negara-negara berkembang agar mampu mandiri. Teori penyadaran telah mengilhami lahirnya model pembangunan yang berpusat pada manusia (people centered development), yang memberikan peran pada warga masyarakat, bukan hanya sebagai subyek melainkan sebagai aktor yang menentukan tujuantujuannya sendiri, menguasai sumber daya yang diperlukan untuk mencapai tujuan- tujuan tersebut, dan mengarahkan prosesproses yang mempengaruhi hidupnya sendiri. Proses penyadaran kepada masyarakat tidak dapat terlepas dari berinteraksinya secara aktif dengan komponen-komponen yang ada di dalamnya. Untuk dapat berinteraksi memerlukan komunikasi sebagai suatu proses di mana partisipan menciptakan dan membagi informasi dengan yang lain sebagai usaha untuk mencapai mutual understanding (pengertian bersama).

Menurut Rogers dan Kincaid (1981) model komunikasi yang sesuai dengan teori penyadaran ini adalah model konvergensi sebagai proses transaksi di antara partisipan, artinya ada proses dialogis yang terjadi sehingga terjadi mutual understanding. Dari uraian di atas menunjukan bahwa teori komunikasi dengan teori pembangunan mempunyai hubungan yang erat.

Dalam kaitannya dengan pembangunan pertanian di pedesaan, kemajuan teknologi informasi yang sangat cepat harus dilihat oleh pemerintah daerah dalam rangka otonomi sebagai peluang besar dalam mempromosikan potensi-potensi investasi unggulan yang ada di wilayahnya. Informasi teknologi dan pasar yang tersedia dan dapat diakses oleh petani dalam mengembangkan agribisnis unggulan tiap daerah sangatlah penting. Oleh karena itu perlu dibangun jaringan komunikasi antara petani dengan pihak luar, baik pemerintah maupun pengusaha sebagai mitra di lapangan. Ada dua faktor strategis yang mendesak untuk dikembangkan, yakni mendorong kembali peran koperasi petani sebagai organisasi ekonomi yang semakin mandiri dan berdaya saing serta membangun Pusat Informasi Agribisnis Komoditas Unggulan. Di era yang kompetitif dan ketat seperti sekarang ini, beragam terobosan-terobosan inovatif harus dilakukan pemerintah daerah untuk menjual potensi-potensi investasi di wilayahnya melalui sistem informasi pertanian sebagai entitas bisnis agar segala potensi investasi mampu dijual dengan kreativitas promosi yang inovatif.

Jadi peran komunikasi dan budaya yang menumbuhkan modernisasi pada masyarakat 
petani sangat berperan penting karena dengan komunikasi yang baik maka akan lebih menjangkau kalangan masyarakat petani di desa-desa.

\section{Kesimpulan}

Peran komunikasi pembangunan dalam modernisasi semakin penting seiring dengan kemajuan iptek dan perkembangan globalisasi yang menuntut kemandirian dan daya saing petani, sehingga perlu dukungan penelitian komunikasi pembangunan pertanian yang lebih luas. Dengan kondisi petani yang serba lemah saat ini hanya mungkin dapat membangun agribisnis dan agribisnis yang efektif dan efisien jika bergabung dalam wadah koperasi pertanian yang mempunyai keunggulan dan kemampuan profesional. Akan tetapi, di era globalisasi sekarang ini telah terbentuk masyarakat informasi yang sangat membutuhkan berbagai informasi yang sesuai dengan kebutuhan petani, sehingga diperlukan upaya untuk meningkatkan pemanfaatan informasi yang tersedia dalam membangun pertanian yang semakin modern menuju kemandirian, daya saing, dan kesejahteraan petani melalui pusat informasi pertanian (PIP) dengan melibatkan seluruh stakeholder di lingkungan pedesaan. Di sampng itu, kebijakan pemerintah pusat dan pemerintah daerah dalam rangka otonomi daerah perlu koordinasi untuk mendorong akselerasi modernisasi pertanian berkelanjutan berbasis potensi daerah dan koperasi pertanian menuju kemandirian, daya saing dan kesejahteraan petani dalam upaya membangun ekonomi kerakyatan sebagai amanah konstitusi nasional.

\section{Daftar Pustaka}

Arroisi. R. H., \& Quraisyin, D. (2015). Arranged Married Dalam Budaya Patriarki (Studi Kasus Komunikasi Budaya) Dalam Pernikahan di Desa Ambunten Kabupaten Sumenep. Jurnal Komunikasi, 9(2) 131-140.
Freire. (1984). Kajian tentang Negara Negara Berkembang. Jakarta: Lentera Ilmu.

Hasan. W., Asmawi, A., \& Rasul, N. (2018). Komunikasi Budaya Dalam Meningkatkan Partisipasi Pemilih di Kota Pariaman. Jurnal Antropologi, 20(2) 179-189.

Jahi. (1988). Komunikasi Massa. Bandung: Tarcito.

Middleton. (1975). Komunikasi Budaya. Jakarta: Kanisius.

Muhammad, A. (2004). Dasar Dasar Komunikasi Organisasi. Jakarta: Bumi Aksara.

Nasrulloh. R. (2015). Komunikasi Budaya Sosioteknologi. Bandung: Simbiosa Rekatama Media.

Rogers. (1976). Teori-teori Sosiologi Pembangunan. Jakarta: Lentera Ilmu.

Rogers. K. (1981). Model- Model Komunikasi dalam Masyarakat. Jakarta: Lentera Ilmu.

Steers, R. M. (1985). Efektivitas Organisasi. Jakarta: Erlangga.

Umar, U. (2017). Pendekatan Social Exchange Perspekstif George C. Homans. TAJDID: Jurnal Pemikiran Keislaman dan Kemanusiaan, 1(1) 97-111.

Undang-Undang Republik Indonesia No 17 Tahun 2007 tentang Rencana Pembangunan Jangka Panjang Nasional. 